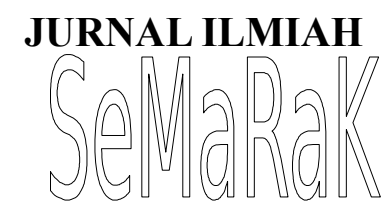

P-ISSN 2615-6849, E-ISSN 2622-3686

Jurnal Semarak,Vol. 2,No.3, Oktober 2019, Hal (1- 9)

@.Prodi Manajemen Fakultas Ekonomi Universitas Pamulang

\title{
HUBUNGAN STRESS KERJA DAN PRODUKTIVITAS KERJA KARYAWAN PADA PT. BANK MANDIRI CLUSTER CILEGON I
}

\author{
Ading Sunarto, S.E., M. M. \\ Assiten Ahli Fakultas Ekonomi Universitas Pamulang \\ Email : dosen02153@unpam.ac.id atau Ading.sunarto2015@gmail.com
}

\begin{abstract}
ABSTRAK
Karya Ilmiah ini bertujuan (1) untuk melihat tingkat stres kerja karyawan PT. Bank Mandiri Cilegon cluster I, (2) untuk mengetahui tingkat produktifitas karyawan PT. Bank Mandiri Cilegon cluster I. (3) mengetahui hubungan kerja stress dan karyawan produktivitas di PT.. Bank Mandiri cluster Cilegon 1. metode deskriptif digunakan dalam penelitian ini, sedangkan sifat kuantitatif pengolahan data dengan menggunakan analisis statistik. PT. Bank Mandiri cluster Cilegon I karyawan digunakan sebagai populasi dan sampel dalam penelitian ini, dengan sebanyak 65 sampel Total responden. Hasil perhitungan penelitian korelasi antara variabel $(X)$ dan stres kerja variabel (Y) produktiviitas kerja karyawan memperoleh nilai 0,60 rxy Kesimpulan (1) tingkat stres kerja pada karyawan PT. Bank. Mandiri cluster Cilegon I tingkat produktivitas yang cukup tinggi (2) bekerja pada karyawan PT. Bank Mandiri. cluster Cilegon saya cukup baik (3) hubungan kerja stres dan produktivitas kerja karyawan PT. Bank Mandiri cluster menunjukkan hubungan variabel kerja stres dan produktivitas kerja yang kuat. Saran .(1) dalam rangka meningkatkan produktiviitas kerja karyawan di PT. Bank Mandiri cluster Cilegon saya maka perusahaan harus memperbaiki stres yang ada di lingkungan perusahaan dengan cara memegang dua arah komunikasi, meluangkan waktu untuk dapat mendengar keluhan karyawan melalui konseling, mengamati kemampuan masing-masing karyawan secara khusus, secara tidak memihak pada karyawan tertentu bersikap adil dan bijaksana dalam memecahkan masalah. (2) perbaikan layanan kesehatan. (3) pembentukan harmonisasi hubungan antara karyawan sebagai kerja tim stres kerja.
\end{abstract}

\section{Kata kunci: Stress Kerja dan Produktivitas Kerja}

\section{ABSTRACT}

The research has purpose to (1) to know the level of work stres on employees of PT. Bank Mandiri Cilegon Cluster I, (2) to find out the level of employee productivity at PT. Bank Mandiri Cilegon Cluster I, (3) to know the relationship of work stres and employee productivity at PT. Bank Mandiri Cluster Cilegon I. Descriptive methods were used in this research, whereas the quantitative nature of data processing by using statistical analysis. PT. Bank Mandiri Cluster Cilegon I employees were used as populations and samples in tihis research, with as many as 65 total sample of respondents. Results of research calculation of the correlation between the variables (X) and work stress Variables (Y) work productivity of employees obtained the value of $0.60 \mathrm{rxy}$. Conclusion (1) levels of work stress on employees of PT. Bank Mandiri Cluster Cilegon I quite high levels of productivity (2) work on the employees of PT. Bank Mandiri Cluster Cilegon I good enough(3) The relationship of work stres and work productivity in employee of PT. Bank Mandiri Cluster Cilegon I touch positive, with a value of $r$ is located at 0.600 .60 or s/d 0.799 indicating the relationship of work stress variables and work productivity is strong. Suggestions (1) in attempt to increase work productivity of employee at PT. Bank Mandiri Cluster Cilegon I then the company 


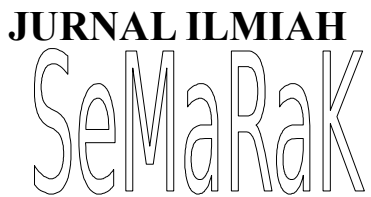

should fix the existing stress in an enterprise environment by way of holding twoway communication, take the time to be able to hear the complaints of employees through counseling, observing the ability of each individual employee specifically, impartially on certain employees be fair and thoughtful in solving problems. (2) improvement of health services. (3) establishment of the harmonization of relations between employees as work stress team work.

\section{Keywords: Job Stress and Work Productivity}

\section{PENNDAHULUAN}

\section{A. Latar Belakaang}

Didalam Undang-Undang Dasar Negara Republik Indonesia di tahun 1945 / UUD 1945 yang tepatnya didalam alinea ke empat pembukaan UUD 1945, lembaga keuangan di dalam dunia perbankan telah dijamin, yang menyebutkan bahwa "melindungi segenap bangsa dan seluruh tumpah darah Indonesia". Didalam teori perlindungan hukum bagi seluruh bangsa Indonesia atau WNI di bidang ekonomi termasuk perlindungan hak konsumen atau nasabah perbankan telah ditentukan secara teoritis didalam alinea ke-4 pembukaan UUD 1945.

Banyaknya tekanan-tekanan dan perubahan-perubahan dalam manajemen organisasi ditimbulkan oleh adanya persaingan sertatuntutan profesionalisme yang semakin kuat didalam lingkungan kerja yang harus dihadapi oleh individu. Potensi kecemasan ditimbulkan oleh lingkungan keluarga dan lingkungan sosial selain dorongan atau tekanan yang berasal dari lingkungan tempat be kerja yang berdampak sangat merugikan sering dialami oleh karyawan di tempat kerja yang dinamakan dengan stres kerja.

Menurut Handoko (2012:200), Stress adalah suatu kondisi dimana ketegangan individu yang dapat mempengaruhi emosi atau kemarahan, proses berpikir serta kondisi individu. Kemampuan individu untuk menghadapi lingkungannya dapat terancam dengan adanya stres yang terlalu besar.Pelaksanaan kerja mereka dapat terganggu sebagai hasil dari perkembangan gejala stress pada diri karyawan. Selain dapat berperan sebagai salah atau merusak tingkat prestatsi kerja, stress juga dapat membantu atau fungsional. Sederhananya berarti bahwa pelaksanaan kerja dapat didorong atau diganggu oleh adanya stress, tergantung seberapa besarnya tingkatan stres yang dialami oleh karyawan-karyawan tersebut.

Produktivitas sendiri menjadi fenomena yang menarik sejak awal industrialisasi, oleh karena itu produktivitas sangatlah penting dalam menciptakan sebuah daya saing pada suatu perusahaan. Guna kepentingan tersebut perusahaan diharapkan dapat melaksanakan semua fungsi organisasi perusahaan dengan jumlah tingkat efisiensi, efektivitas dan produktivitas yang cukup tinggi. Setiap organisasi perusahaan yang memiliki keinginnan untuk tumbuh serta berkembang akan selalu berusaha untuk meningkatkan jumlah 


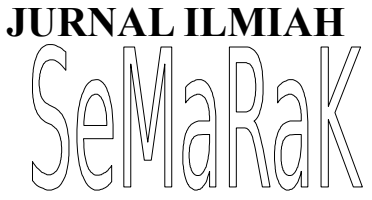

produktivitas kerjanya sebagai system organisasi tersebut dan meminimalkan dampak-dampak yang nantinya dapat merugikan pihak perusahaan.

Menurut Siagian (2012:17), pengertian produktivitas ialah kemampuan mendapatkan kegunaan yang sebesar besarnya dari sarana-sarana dan prasarana yang telah dimiliki dengan menciptakan suatu output yang optimal, apabila mungkin yang maksimal. Dari penjelasan tersebut menjelaskan bahwa apabila produktivitas kerja karyawan cukup tinggi, maka karyawan dikatakan bisa serta mampu menghasilkan total hasil yang sama dengan total input yang lebih besar menghasilkan jumlah yang lebih besar dibanding dengan jumlah masukan. Namun sebaliknya apabila produktivitas karyawan rendah, maka karyawan tidak mampu menghasilkan output atau produksi yang sama bahkan tidak mampu mencukupi target yang telah diterapkan oleh perusahaan.

Agar motivasi pekerjaan dan individu karyawan tidak terjadi yang namanya stres kerja di tempat ia bekerja, maka produktivitas harus meningkat yang artinya bahwa performansi haruslah baik yang akan menjadi feedback didalam usaha. Salah satu caraindividu meningkatkan yang namanya produktivitas yaitu dengan langkah-langkah bagaimana seorang karyawan membangun sebuah hubungan ikatan dengan seorang atasannya dan bawahannya di mana tempat iabekerja. Stress kerja pada individu ditimbulkan oleh adanya banyak tekanan yang diterima oleh karyawan. Tekanan yang menyebabkan stress di tempat kerja tidak akan dialami oleh mental serta kemampuan dan keadaan fisik karyawan yang berkontribusi didalam memberikan produktivitas yang baik pada suatu perusahaan.

Tabel 1

Tingkat absensi dari karyawan PT. Bank Mandiri Cluster Cilegon I

(periode Januari 2018 sampai dengan Desember 2018)

\begin{tabular}{|c|c|c|}
\hline Bulan & Jumlah Karyawan & $\begin{array}{c}\text { Data Kehadiran } \\
\text { Karyawan }\end{array}$ \\
\hline Januari & 175 & $98 \%$ \\
\hline Februari & 177 & $96 \%$ \\
\hline Maret & 178 & $97 \%$ \\
\hline April & 176 & $96 \%$ \\
\hline Mei & 178 & $95 \%$ \\
\hline Juni & 178 & $97 \%$ \\
\hline Juli & 180 & $90 \%$ \\
\hline Agustus & 180 & $89 \%$ \\
\hline September & 179 & $94 \%$ \\
\hline Oktober & 178 & $94 \%$ \\
\hline November & 180 & $93 \%$ \\
\hline Desember & 180 & $92 \%$ \\
\hline
\end{tabular}

Sumber : Data absensi karyawan PT. Bank Mandiri Cluster Cilegon I periode tahun 2018

Tabel diatas menunjukkan bahwa tingkat ketidakhadiran karyawan terus menurun setiap bulan dari bulan Januari 2018 sampai bulan Desember 2018. Informasi dari hasil penelitian menyatakan bahwa bervariasinya tingkat absensi karyawan diindikasikan adanya banyak faktor yang menyebabkan, salah satu nya yaitu faktor keadaan atau ada tidaknya stres pada karyawan dalam perusahaan.

\section{B. Rumusan Masalah}

Setelah dilakukan peniabaran dalam analisis. dapat dibuat suatu peruumusan massalah adalah:

1. Bagaimanakah tingkat stress keria pada karvawan PT. Bank Mandiri Cluster Cilegon 1?

2. Bagaimanakah tingkat produktivitas keria pada karvawan PT. Bank Mandiri Cluster Cilegon 1?

3. Bagaimanakah hubungan stress 
keria dan produktivitas keria bada karvawan PT. Bank Mandiri Cluster Cilegon 1 ?

\section{Tujuan Dari Penelitian}

Adapun tujuan penelitian yang ingin dicapai dalam penelitian ini adalah:

1. Untuk mengetahuitingkat stress keria karvawan bada PT. Bank Mandiri Cluster Cilegon 1.

2. Untuk mengetahui tingkat produktivitas keria karvawan pada PT. Bank Mandiri Cluster Cilegon 1.

3. Untuk mengetahuihubungan stress kerja dan produktivitas keria karvawan pada PT. Bank Mandiri Cluster Cilegon 1.

\section{TINJAUAN PUSTAKA}

\section{A. Pengertian Stres Kerja}

Menurut Siagian (2012:300) stres adalah kondisi ketegangan yang dapat berpengaruh terhadap tingkat emosi, jalan pikiran serta kondisi fisik seseorang. Seseorang menjadi tidak mampu berinteraksi secara positif di lingkungannya diakibatkan oleh adanya stres yang tidak diatasi dengan baik. Artinya bahwa prestasi kerja karyawan akan berpengaruh negatif dan tentunya akan menghadapi berbagai gejala negatif lainnya. Stres kerja merupakan suatu kondisi dan keadaan yang menimbulkan adanya ketidakseimbangan fisik dan psikologi seseorang yang mempengaruhi tingkat emosi, cara berpikir, dan kondisi seseorang karyawan (Rivai, 2005:516).

Kata stres sendiri pada mulanya berasal dari bahasa latin yaitu dari sebuah kata "stringere" yang berarti ketegangan, serta tekanan. Stres adalah reaksi negatif dari individu-individu yang mendapat tekanan lebih tinggi yang dibebankan kepeda mereka akibat dari tuntutan-tuntutan, hambatanhambatan, atau adanya peluang yang terlalu berlebih (Robbins, 2010:16).

Stres adalah reaksi yang tidak diinginkan yang timbul sebab besarnya tuntutan lingkungan pada individu dimana harmoni keseimbangan antara kekuatan dan kemampuan akan terganggu (Atmaningtyas, 2010:1).

\section{B. Penggertian Produktivitas Kerja}

Hasibuan

berpendapat bahwa produktivitas merupakan perbandingan antara hasil atau output dengan masukan atau input. Apabila produktivitasnya naik ini kemungkinkan hanya diperoleh adanya peningkatan efisiensi (waktu, bahan-tenaga) dan sistem kerja, teknik produksi dan dengan adanya peningkatan keterampilan dan kreatifitas dari tenaga kerja karyawan.

Menurut Manullang (2008:57) produktivitas kerja dipengaruhi oleh faktor-faktor sebagai berikut : a. Kompeten, yaitu faktor penting yang wajib dipunyai oleh seorang pengawas pelaksana ataupun pemimpin. b. Experience, faktor dalam pengalaman sangat dekat kaitannya dengan intelegensi, yaitu kecakapan karyawan dalam melaksanakan kewajiban tertentu yang hasilnya ditentukan oleh pengalaman dan disupport oleh kecerdasan berfikir. c. Usia, lazimnya karyawan yang usia sudah tua memiliki tenaga fisik relative terbatas ketimbang karyawan yang masih usia muda. Untuk itu, karyawan yang lebih muda 
dikenakan pekerjaan lebih banyak karena fisiknya lebih kuat. d. Kesehatan fisik, keadaan fisik erat kaitannya dengan tugas yang dihadapi. Contohnya pekerjaan yang memerlukan tenaga fisik yang kuat serta penglihatan yang tajam. e. Pendidikan, pendidikan sering dikaitkan dengan latihan-latihan yang umunya menunjukan kesanggupan dalam bekerja. f. Bakat dan sikap, memiliki fungsi penting dalam menunjang keberhasilan dalam bekerja. Bakat dan sikap berkaitan dengan sifatsifat spesial dari kepribadian individu dan dianggap bukan dipengaruhi oleh lingkungan sekitar.

\section{METODE PENELITIAN}

Penelitian karya ilmiah ini dibuat dengan memakai pendekatan metode survei. Jenis dari penelitian ini dibuat menggunakan jenis penelitian deskriptif kuantitatif. Sifat dari penelitian ini yaitu eksplanatori. Populasi dalam penelitian ini yaitu semua karyawan di PT. Bank Mandiri (persero) Tbk. Cluster Cilegon I yang beralamat di beralamat di Jl Pasar Baru Kranggot No.2 Kota Cilegon, Banten dengan populasi yang total jumlahnya adalah 180 orang serta dengan memakai metode proportional random sampling dengan jumlah total sampel sebanyak 65 responden.

Didalam penelitian ini metode pengumpulan data-datayang digunakan adalah sebagai berikut:

1. Daftar kuesioner atau pertanyaan (questionnaire) yang disampaikan kepada para karyawan PT. Bank Mandiri (persero) Tbk. Cluster Cilegon Iyang dijadikan sampel.

2. Wawancara kepada responden (interview) yang ditujukan ke

3. karyawanPT. Bank Mandiri (persero) Tbk. Cluster Cilegon Idan pihak-pihak yang mempunyai berhak serta berwenang memberikan data-data penelitian yang berhubungan dengan kebutuhan penelitian yaitu bagian Departemen SDM.

4. Dokumentasi, yaitu melaluicaramengumpulkan serta mempelajari beberapa dokumen yang relevan terkait dengan penelitian serta mendukung didalam penelitian, misalnya profil singkat perusahaan tersebut, jumlah seluruh karyawan, serta struktur organisasi perusahaannya.

\section{HASIL PENELITIAN}

Tabel 2. Hasil Analisis Item Instrumen Variabel Sres \begin{tabular}{|c|c|c|}
\multicolumn{3}{c}{ Kerja (X) } \\
\hline Butir instrument & thitung $>$ t table & Keterangan \\
\hline 1 & $3,3546>1,6694$ & Valid \\
\hline 2 & $3,7752>1,6694$ & Valid \\
\hline 3 & $4,0426>1,6694$ & Valid \\
\hline 4 & $6,0197>1,6694$ & Valid \\
\hline 5 & $2,3490>1,6694$ & Valid \\
\hline 6 & $4,3850>1,6694$ & Valid \\
\hline 7 & $4,3417>1,6694$ & Valid \\
\hline 8 & $4,6557>1,6694$ & Valid \\
\hline 9 & $1,7935>1,6694$ & Valid \\
\hline 10 & $5,8658>1,6694$ & Valid \\
\hline 11 & $2,9759>1,6694$ & Valid \\
\hline 12 & $3,6665>1,6694$ & Valid \\
\hline
\end{tabular} Sumber : Data olahan 2019

Berdasarkan hasil olah data di atas menunjukkan semua instrument stress kerja adalah valid. Hal ini menjelaskan bahwa instrument yang sudah dibuat adalah benar-benar dapat mngenalisa serta mengukur variable stress kerja, yang kemudian data hasil ini dapat ditindaklanjuti pada tahap analisis berikutnya, yakni uji reliabilitas.

Tabel 3. Hasil Analisis Item Instrumen Variabel Produktivitas Kerja (Y) 
JURNAL ILMIAH

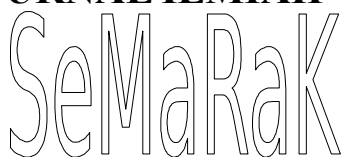

\begin{tabular}{|c|c|c|}
\hline Butir instrument & t hitung $>$ t table & Keterangan \\
\hline 1 & $6,5858>1,6694$ & Valid \\
\hline 2 & $5,7827>1,6694$ & Valid \\
\hline 3 & $3,9388>1,6694$ & Valid \\
\hline 4 & $7,7598>1,6694$ & Valid \\
\hline 5 & $7,9860>1,6694$ & Valid \\
\hline 6 & $6,3748>1,6694$ & Valid \\
\hline 7 & $7,3125>1,6694$ & Valid \\
\hline 8 & $4,9285>1,6694$ & Valid \\
\hline 9 & $4,4179>1,6694$ & Valid \\
\hline 10 & $6,1655>1,6694$ & Valid \\
\hline 11 & $6,9333>1,6694$ & Valid \\
\hline 12 & $7,6538>1,6694$ & Valid \\
\hline
\end{tabular}

Sumber : Data olahan 2019

\section{Analisis Koefisien Korelasi}

Sesuai dengan tujuan penelitian, maka dipergunakan perhitungan korelasi dengan menggunakan Rumus Angka Kasar (RAW SCORE) dari Pearson untuk mengetahui korelasi antara kedua variable.

$r_{x y}=\frac{n \sum X Y-\left(\sum X\right)\left(\sum Y\right)}{\sqrt{\left\{n \sum X^{2}-\left(\sum X\right)^{2}\right\}\left\{n \sum Y^{2}-\left(\sum Y\right)^{2}\right\}}}$

Penjelasan:

$\mathrm{r} \quad=$ Yaitu koefisien dari korelasi Pearson

$\mathrm{n} \quad=$ Yaitu jumlah dari responden

$\mathrm{X} \quad=$ Yaitu variabel Independen

$\mathrm{Y} \quad=$ Yaitu variabel Dependen

Dengan pedoman:

Tabel 3. Interprestasi Nilai KoefisienKorelasi

\begin{tabular}{|c|c|}
\hline Interval koefisien & Tingkat hubungan \\
\hline $0,00-0,199$ & Sangat rendah \\
\hline $0,20-0,399$ & Rendah \\
\hline $0,40-0,599$ & Sedang \\
\hline $0,60-0,799$ & Kuat \\
\hline $0,80-1,000$ & Sangat kuat \\
\hline
\end{tabular}

Didalam menentukan ada atau tidaknya hubungan stress kerja terhadap produktivitas kerja karyawan digunakan analisis koefisien korelasi, dengan rumus :

$\mathrm{X}=$ Stres Kerja

$\mathrm{Y}=$ Produktivitas Kerja

$$
\begin{aligned}
& r_{x y}=\frac{n \sum X Y-\left(\sum X\right)\left(\sum Y\right)}{\sqrt{\left\{n \sum X^{2}-\left(\sum X\right)^{2}\right\}\left\{n \sum Y^{2}-\left(\sum Y\right)^{2}\right\}}} \\
& r_{x y}=\frac{65 \times 158553-(3123)(3280)}{\sqrt{\left\{65 \times 152576-(3123)^{2}\right\}\left\{65 \times 166526-(3280)^{2}\right\}}} \\
& r_{x y}=\frac{10305945-10243440}{\sqrt{\{9917440-9753129\}\{10824190-10758400\}}} \\
& r_{x y}=\frac{62505}{\sqrt{(164311)(65790)}}
\end{aligned}
$$

$r_{x y}=\frac{62505}{103971,25}$

$r_{x y}=0,60$

Hasil koefisienn korelasi (r) sebesarr 0,60 dapat dikatakan bahwa hubungan diantara variabel $\mathrm{X}$ (stres kerja) dengan variabel Y (produktivitas kerja), menunjukkan hubungan yang kuat. Berdasarkan yang terdapat dalam ketentuan nilai $r$ dan pada pedoman dan panduan interprestasi koefisien korrelasi yaitu jika $r>0$ maka terdapat hubungan posiitif, dan apabila interval koefisien korelasi berada pada nilai 0,60 - 0,799 maka hal itu menunjukan bahwa tiingkat hubungan antara tres kerja dengan produktiviitas kerja adalah "Kuat".

Menentukan Uji Signifikasi (Nilai Uji-t)

Pengujian, hypotesis:

$\mathrm{H}_{\mathrm{o}}$ : yaitu koefisien korelasi tidaklah signifikan

$\mathrm{H}_{\mathrm{a}} \quad$ : yaitu koefisien korelasi adalah signifikan

Ketentuan:

Teriima $H_{0}$, jika $t_{\text {hitung }}<t_{\text {tabel, }}$ Teriima $H_{a}$ jika $t_{\text {hitung }}>t_{\text {tabel }}$

Tolak $\mathrm{H}_{\mathrm{o}}$, jika $\mathrm{t}_{\text {hitung }}>\mathrm{t}_{\text {tabel, }}$ Tolakk $\mathrm{H}_{\mathrm{a}}$ jika $\mathrm{t}_{\text {hitung }}<\mathrm{t}_{\text {tabel }}$

Untuk menentukan nilai $t_{\text {hitung }}$ dipergunakan rumus sebagai berikut:

$t=\frac{r \sqrt{n-2}}{\sqrt{1-r^{2}}}$

$\mathrm{t}_{\text {tabel }}=\mathrm{t}(\alpha) \cdot(\mathrm{n}-1)$

$\mathrm{t}=\frac{0,60 \sqrt{65-2}}{\sqrt{1-(0,60)^{2}}}$

$\mathrm{t}_{\text {tabel }}=\mathrm{t}(5 \%) .(65-1)$

$\mathrm{t}=\frac{0,60 \times 7,937}{0,999516}$

$\mathrm{t}_{\text {tabel }}=\mathrm{t}(0,05) \cdot(64)$

$\mathrm{t}=\frac{4,7623}{0,8}$

$\mathrm{t}_{\text {tabel }}=1,670$

$\mathrm{t}=5,95$ 
Karena pada tabel tidak diketemukan $\mathrm{dk}=64$ maka dicari lewat perhitungan interpolasi sebagai berikut:

Diketahuii : $\mathrm{t}(0,05 ; 60)=1,671$ (lihat tabel distribusi t pada lampiran) $\mathrm{t}(0,05 ; 120)=1,658$ (lihat distribusi t pada lampiran)

maka untuk dk 64

$$
\begin{aligned}
& \frac{64-60}{120-64}=\frac{x-1,671}{1,658-x} \\
& \frac{4}{56}=\frac{x-1,671}{1,658-x} \\
& 4 X-6,632=93,576-56 X \\
& 4 X+56 X=100,208 \\
& 60 X=100,208 \\
& X=\frac{100,208}{60} \\
& X=1,670
\end{aligned}
$$

Dari hasil kalkulasi diatas didapatkan $t_{\text {hitung }}(5,95)$ dan $t_{\text {tabel }} 1,670$. Karena $t_{\text {hitung }}>\mathrm{t}_{\text {tabel }}$ maka terima $\mathrm{H}_{\mathrm{a}}$ dan tolak $\mathrm{H}_{\mathrm{o}}$ Dengan demikian dapat disiimpulkan bahwa terdapat hubbungan antara stress kerja dan produktivitas kerja karyawann pada PT. Bank Mandiri (persero) Tbk. Cluster Cilegon I. Dan karena $t_{\text {tabel }}(0,05 ; 64)$ adalah 1,670 sehingga daerah keputusan dapat diketahui pada gambar berikut ini:

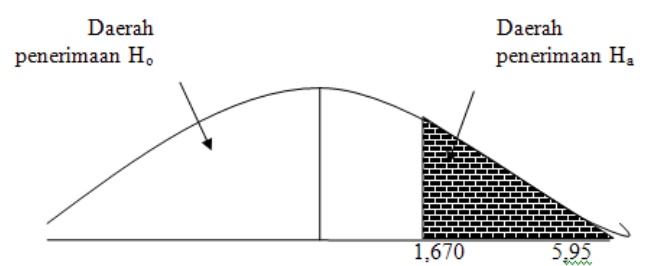

\section{Gambar 1. Area Keputusan}

Dari perhitungan serta gambar 1
diatas dapat diketahuii bahwa
$\mathrm{t}_{\text {hitung }}(5,95)$ lebih besar dari $(1,670)$ pada
taraf signifikan $5 \%$ berada didaerah
penerimaan $\mathrm{H}_{\mathrm{a}}$ (untuk uji pihak kanan)
maka dengan demiikian $\mathrm{H}_{\mathrm{o}}$ ditolak dan
$\mathrm{H}_{\mathrm{a}}$ diteriima.Jadi hipotesa yang

diajukkan peneliti pada bab 1 diterima yaitu: "Terdapat hubungan stres kerja terhadap produktivitas kerja karyawan PT. Bank Mandiri (persero) Tbk. Cluster Cilegon I".

\section{KESIMPULAN DAAN SARAN}

\section{A. Kesimpulaan}

Berdasarkan hasiil dari penelitian yang telah dilakukan menngenai stres kerja dan produktivitas kerja pada karyawan PT. Bank Mandiri (persero) Tbk. Cluster Cilegon I dengan menggunakan analisa secara korelasi product moment maka dapat ditarik kesimpulan antara lain :

1. Tingkat stres kerja pada karyawan PT. Bank Mandiri (persero) Tbk. Cluster Cilegon I cukup tinggi, hal ini didasarkan pada hasil jawaban quesioner stres kerja seluruh ressponden yang menjawab "Sangat Setuju" sebanyak 207 atau 26,5\%, "Setuju" sebanyak 448 atau 57,4\%, "Ragu-ragu" sebanyak 47 atau 6,02\%, "Tidak Setuju" seebanyak 77 atau 9,87\% dan "Sangat Tidak Setuju" sebanyak 1 atau $0,12 \%$.

2. Tingkat produktiivitas kerja pada karyawaan PT. Bank Mandiri (persero) Tbk. Cluster Cilegon I cukup baik, hal ini didasarkan pada hasil jawaban quesioner produktivitas kerja seluruh responden yang menjawab "Sangat Setuju" sebanyak 221 atau 28,3\%, "Setuju" sebanyak 502 atau 64,3\%, "Ragu-ragu" sebanyak 53 atau 6,79\%, "Tidak Setuju" sebanyak 4 atau $0,51 \%$ dan "Sangat Tidak Setuju" sebanyak 0 atau $0 \%$.

3. Stres kerja
produktiviitas kerja pada 


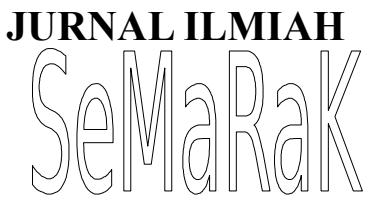

karyawan PT. Bank Mandiri (persero) Tbk. Cluster Cilegon I berhubungan positif, dapat diliihat dari besarnya nilai $r$ sebesar 0,60 atau terletak pada $0,60 \quad \mathrm{~s} / \mathrm{d} \quad 0,799 \quad$ yang menunjukkan hubungan antara variable stres kerja dan variabel produktivitas kerja adalah kuat. Berdasarkan hasil uji hipotesis diperoleh $\mathrm{t}$ hitung $(5,95)>\mathrm{t}$ tabel $(1,670)$, artinya Ho ditolak $\mathrm{Ha}$ diterima. Maka dari itu dapat disimpulkan bahwa terdapat hubbungan antara stres kerja dengan produktivitas kerja.

\section{B. Saran}

Dalam usaha meningkatkan produktiviitas kerja karyawan PT. Bank Mandiri (persero) Tbk. Cluster Cilegon I maka perusahaan hendaknya :

1. Membenahi stres kerja yang ada di lingkungan perusahaan dengan jalan mengatur kembali hal-hal yang menjadi penyebab stres kerja secara professional, misalnya :
a. Mengadakan komunikasi dua arah. dapat mendengar keluhan karyawan melalui
b. Meluangkan waktu untuk konseling.
c. Mencermati kemampuan masing-masing individu karyawan secara spesifik.
d. Tidak memihak pada karyawan tertentu, bersikap adil dan bijaksana dalam memecahkan permasalahan.

2. Peningkatan pelayanan kesehatan harus diperhatikan untuk karyawan.
3. Kerjasama perlu ditingkatkan harmonisasi hubungan kerja antar karyawan sebagai team work.

4. Untuk mengurangi kejenuhan karyawan dalam bekerja, perusahaan hendaknya memberikan sarana dan prasarana untuk refreshing paling tidak setahun sekali.

\section{DAFTAR PUSTAKA}

Atmaningtyas, Naila, "Kiat Hidup Bahagia Tanpa Stress \& Depresi", Penerbit Getar Hati, Yogyakarta, 2010.

Handoko, Hani T, "Manajemen Personalia \& Sumberdaya Manusia”, Edisi Kedua, Penerbit BPFE, Yogyakarta, 2012.

Hasibuan S.P, Malayu, "Manajemen Sumber Daya Manusia”, Edisi Revisi, Penerbit PT. Bumi Aksara, Jakarta, 2009.

Manullang, H, "Manajemen Personalia". Penerbit Gadjah Mada Press, Yogyakarta, 2008.

Rivai, Veithzal, Manajemen Sumber Daya Manusia untuk Perusahaan, Penerbit Raja Grafindo Persada, Jakarta, 2005.

Robbins, Stephen, P, “Manajemen”, Edisi Kesepuluh, Penerbit Erlangga, Jakarta, 2010.

Siagian, Sondang, P, "Manajemen Sumber Daya Manusia”, Penerbit PT. Bumi Aksara, Jakarta, 2012.

Sugiyono, "Metode Penelitian Kuantitatif dan Kualitatif", Alfabeta, Bandung, 2009. 
Pasaribu, V. L. D., \& Krisnaldy, K. (2018). ANALISIS KEPUASAN JAMA'AH

\section{Peraturan Perundang-Undangan}

PADA KINERJA DEWAN KEMAKMURAN MASJID Undang-Undang Dasar Negara Republik Indonesia Thun AL-HIDAYAH PERIODE 1945.

TAHUN 2017. KREATIF:

Jurnal Ilmiah Prodi

Manajemen Universitas

Pamulang, 6(4), 41-51. 